\title{
Propolis extract in postharvest conservation of Solo papaya cv. 'Golden'
}

\section{Extrato de própolis na conservação pós-colheita de mamão Solo cv. 'Golden'}

\author{
Flávia Regina Passos ${ }^{1 *}$; Fabrícia Queiroz Mendes²; Marina de Carvalho Eufrásio \\ Pinto $^{1}$; Emiliane Andrade Araújo ${ }^{3}$; André Mundstock Xavier de Carvalho ${ }^{2}$
}

\begin{abstract}
The high perishability of papaya (Carica papaya L.) reduces the lifespan as well as limits marketing. Coating fruit is an alternative process to aid food preservation. The objective of this study was to evaluate the effects of propolis extract coating on physicochemical characteristics of papaya stored at room temperature. Solo papayas cv. 'Golden' were randomly divided into five postharvest treatments: three forms of dip-coating ( $70 \%$ alcohol, hydroalcoholic extract of propolis at $2.5 \%$, and hydroalcoholic extract of propolis at 5\%) and two controls (one uncoated and one with refrigerated uncoated fruit). Each four days, weight loss, fruit firmness, soluble solids (SS), titratable acidity (TA), SS/ TA ratio, and hydrogen potential $(\mathrm{pH})$ were evaluated throughout 12 days of storage. A sensory analysis was performed on the fourth day of storage, being appraised by untrained tasters through acceptance testing. Refrigerated, $2.5 \%$ propolis, and $5 \%$ propolis treatments promoted the lowest weight losses. Flesh firmness of $5 \%$ propolis treatment was superior to that of control, alcohol, and $2.5 \%$ propolis treatments. Moreover, $5 \%$ propolis treatment achieved a great SS, differing only from alcohol treatment. Both TA and SS/TA had no variations among treatments, but along storage time. Flesh $\mathrm{pH}$ of refrigerated papaya showed significant differences in relation to other treatments. Also, refrigerated fruit presented chilling injury symptoms. Propolis-coated papaya showed sensory acceptability similar to those of the other treatments on the $4^{\text {th }}$ day of storage. Therefore, propolis coating renders Solo papaya cv. 'Golden' a promising alternative to control fruit weight losses and firmness.
\end{abstract}

Key words: Carica papaya L. Coating. Propolis. Storage.

\section{Resumo}

A alta perecibilidade do mamão (Carica papaya L.) reduz sua vida útil limitando sua comercialização. Os revestimentos são uma das alternativas para auxiliar na conservação de alimentos. Objetivouse avaliar os efeitos do revestimento com extrato de própolis nas características físico-químicas do mamão, armazenado sob temperatura ambiente. Mamões Solo cv. 'Golden' foram selecionados e divididos aleatoriamente em cinco tratamentos pós-colheita, sendo três formas de revestimento por imersão ("álcool 70\%", "extrato hidroalcoólico de própolis a 2,5\%", "extrato hidroalcoólico de própolis a 5\%") e dois controles (um sem revestimento e outro em que os frutos não foram revestidos e mantidos sob refrigeração). As variáveis perda de massa, firmeza da polpa, sólidos solúveis (SS), acidez titulável

\footnotetext{
${ }^{1}$ Mestres, Programa de Pós-Graduação em Agronomia, Produção Vegetal, Universidade Federal de Viçosa Campus de Rio Paranaíba, UFV/CRP, Rio Paranaíba, MG, Brasil. E-mail: flaviapassos1@yahoo.com.br; marinaeufrasio@gmail.com

2 Profs. Drs., Programa de Pós-Graduação em Agronomia, Produção Vegetal, UFV/CRP, Campus de Rio Paranaíba, Rio Paranaíba, MG, Brasil. E-mail: fabricia.mendes@ufv.br; andre.carvalho@ufv.br

${ }^{3}$ Prof $^{\mathrm{a}} \mathrm{Dr}^{\mathrm{a}}$, Curso de Engenharia de Alimentos, Universidade Federal do Triângulo Mineiro, UFTM, Uberaba, MG, Brasil. E-mail: emiliane@icte.uftm.edu.br

* Author for correspondence
} 
(AT), relação entre sólidos solúveis e acidez titulável (SS/AT) e potencial hidrogeniônico (pH), foram avaliadas em intervalos de 4 dias por 12 dias de armazenamento. Realizou-se análise sensorial no quarto dia de armazenamento dos mamões, avaliados por provadores não treinados através do teste de aceitação. Os tratamentos pós-colheita "refrigerado", "própolis 2,5\%" e "própolis 5\%" propiciaram menor perda de massa. A firmeza da polpa para o tratamento pós-colheita "própolis 5\%" apresentouse superior aos tratamentos pós-colheita "controle", "álcool" e "própolis 2,5\%". O teor de SST foi maior para o tratamento pós-colheita "própolis 5\%", que diferiu somente do tratamento pós-colheita "álcool”. A AT e a relação SS/AT não variaram com os tratamentos pós-colheita, variando somente com o tempo de armazenamento. $\mathrm{O} \mathrm{pH}$ dos mamões refrigerados apresentaram diferenças significativas em relação aos demais tratamentos pós-colheita. Os frutos do tratamento "refrigerado" apresentaram injúria pelo frio. Mamões revestidos com extrato de própolis apresentaram aceitação sensorial semelhantes aos demais tratamentos pós-colheita no quarto dia de armazenamento. O revestimento de extrato de própolis pode ser uma alternativa promissora no controle da perda de massa e manutenção da firmeza da polpa em mamão Solo cv. 'Golden'.

Palavras-chave: Carica papaya L.. Revestimento. Própolis. Armazenamento.

\section{Introduction}

Papaya (Carica papaya L.) is a member of the Caricaceae family, originating in the tropical America. India is the largest papaya producer followed by Brazil, accounting for $45 \%$ of the world's papaya production (FAO, 2014). The Northeast is the largest Brazilian producing region, in particular the state of Bahia, followed by the Southeast, especially the Espirito Santo state. Both of them are responsible for nearly $90 \%$ national production, according to data by IBGE (2013). The two grand groups of papaya grown in Brazil are Solo and Formosa. The first is intended for domestic and foreign markets (e.g., cv. 'Sunrise Solo' and 'Golden'), whereas the second is for the domestic exclusively (e.g., cv. 'Tainung 01' and 'Tainung 02') (SERRANO; CATTANEO, 2010; ROCHA et al., 2005).

Papaya is a climacteric fruit whose ripening occurs rapidly after harvesting physiologically ripe fruit; this process is triggered by ethylene and respiratory rate upsurge (CHITARRA; CHITARRA, 2005). For this reason, ripening control constitutes a key factor to increase postharvest longevity (ALI et al., 2011), which is critical for both internal trade and exports (SILVA et al., 2014).

Biodegradable-polymer coatings offer a cost-benefit for fruit packaging under modified atmosphere (ALI et al., 2015; SILVA et al., 2014;
DAIUTO et al., 2012). This technique has been continually used as treatment to extend the shelf life of fruits, to reduce losses, and to maintain the quality (ALI et al., 2015; PIZATO et al., 2013; PASTOR et al., 2011; MENEGUEL et al., 2008). Generally, these coatings consist of a biopolymer (polysaccharide and/ or protein) film carrying a functional agent (flavors, colorants, antioxidants, and antimicrobial agents) (CHITARRA; CHITARRA, 2005).

Atmosphere modification is achieved by the interaction between natural respiration and permeable gas exchange through coating, which slows ripening and senescence (ALI et al., 2011). In addition, coating helps increase $\mathrm{CO}_{2}$ concentration and water vapor, as well as depleting $\mathrm{O}_{2}$ levels (ALI et al., 2015). Gas exchange intensity of a coating depends on its characteristics, such as thickness, type, and chemical composition. The best results are attained when there is a suitable balance between gas and water-vapor coating permeability which, in turn, vary with fruit type, variety, weight, maturation stage, and temperature (CHITARRA; CHITARRA, 2005).

Propolis and its extracts possess antimicrobial activity and contain some hydrophobic compounds able to improve a few properties of biodegradable coatings on fruits (ALI et al., 2015; ALI et al., 2014; ZAHID et al., 2013). Ali et al., 2015 and Zahid et al. (2013) reported that, in bell pepper 
and in dragon fruit respectively, propolis coating presented excellent antifungal properties, providing an effective barrier to limit mycelial growth and germination of Colletotrichum capsici spores (the fungus responsible for anthracnose). Moreover, Ali et al. (2014) showed that propolis extract, when combined with cinnamon oil, acts as an efficient bio-fungicide against $C$. capsici, and slowing changes in weight, flesh firmness, peel color, and concentration of soluble solids in peppers. Several studies have reported the efficiency of propolis on gram-positive bacteria, however, having a limited activity towards gram-negative ones (TORLAK; SERT, 2013; UZEL et al., 2005). Furthermore, Daiuto et al. (2012) observed less weight loss and $\mathrm{CO}_{2}$ production in avocados in application of propolis extract in combination with vegetable wax.

Given the above, this study aimed to evaluate the effects of propolis extract coating on physicochemical characteristics of Solo papaya cv. 'Golden' stored under ambient temperature.

\section{Material and Methods}

The experiments were conducted at the Laboratory of Chemical Analysis of the Food Institute of Agricultural Sciences, Federal University of Viçosa, Campus of Rio Paranaíba (UFV/CRP), Minas Gerais state, Brazil.

\section{Propolis extract preparation}

Propolis was collected from beehives of honey bees (Apis mellifera L.), brown type, between October 2010 and March 2011, in apiaries located in the southern Paraná, Brazil, near a typical bee pasture mixed with rain forest ecosystem.

Crude propolis was first subjected to precleaning, with cold wash, and kiln dried (Cienlab - Campinas, Brazil) under an air circulation at 60 ${ }^{\circ} \mathrm{C}$ for $10 \mathrm{~h}$. Next, it was packed into polyethylene bags and freeze stored (Eletrolux - São Paulo,
Brazil) at $-5^{\circ} \mathrm{C}$ for $12 \mathrm{~h}$. Then, a 100 -g aliquot was ground in a blender (Arno - São Paulo, Brazil), packaged into amber glass bottles; and the volume was made to $1 \mathrm{~L}$ with $70 \%$ ethanol ( $1^{\text {st }}$ dilution). The suspension was allowed to stand for 5 days at room temperature, with hand stirring for $1 \mathrm{~min}$ once every day; afterwards, it was filtered through quantitative filter paper (JP 42; Quanty ${ }^{\circledR}$; blue strip) (CARVALHO et al., 2013). Last, the hydroalcoholic extract of propolis was diluted in $70 \%$ ethanol to final concentrations of $2.5 \%$ and $5.0 \%$ ( $2^{\text {nd }}$ dilution $)$.

\section{Fruit collection, selection, and evaluation}

Solo papayas, cv. 'Golden', were purchased from the central distribution market (CEASA) of Contagem city, Minas Gerais state. Fruit selection was based on peel color, at index 2 (within 15 to 25 yellow surface), according to the Programa Brasileiro para a Modernização da Horticultura (2005).

\section{Experimental design}

The fruit were chosen by uniformity, peel color, and ripeness, and then randomly divided into 5 groups, to which were applied the following postharvest treatments:

1. Control - fruit without coating

2. Alcohol - fruit coated with $70 \%(\mathrm{v} / \mathrm{v})$ ethanol

3. $2.5 \%$ propolis - fruit coated with $2.5 \%(\mathrm{w} / \mathrm{v})$ of propolis hydroalcoholic extract

4. $5 \%$ propolis - fruit coated with $5 \%(\mathrm{w} / \mathrm{v})$ of propolis hydroalcoholic extract

5. Refrigerated - uncoated fruit refrigerated at $9 \pm$ $1^{\circ} \mathrm{C}$.

Coatings were applied by dipping the fruit into the above-mentioned solutions individually for five s. After that, they were placed horizontally on a nylon screen to drain the excess fluid, for approximately five min. Then, fruit of all treatments, 
except refrigerated, were placed on benches in a completely randomized design under the following storage conditions: $20 \pm 5{ }^{\circ} \mathrm{C}$ and $75 \pm 5 \%$ relative humidity $(\mathrm{RH})$. Yet those of refrigerated treatment were stored at $9 \pm 1{ }^{\circ} \mathrm{C}$ (within the critical range). The Safety Minimum Temperature (SMT) for papaya ranges from 7 to $12{ }^{\circ} \mathrm{C}$, at a relative humidity (RH) of $85 \pm 5 \%$.

\section{Analyses of the variables}

The experimental units underwent several analyses such as weight loss (non-destructive), firmness, soluble solids (SS), titratable acidity (TA), SS/ TA ratio, and hydrogen potential $(\mathrm{pH})$ (destructive), according to the methods described by Instituto Adolfo Lutz (2004). Prior to treatment application, fruit were evaluated (time 0 ); then, evaluations were carried out at 4,8 , and 12 days of storage, with eight replications for non-destructive group and six for the destructive one. Weight loss was measured using a semi-analytical electronic balance (BL-320H model; Splabor - Presidente Prudente, Brazil) with $0.001-\mathrm{g}$ sensitivity. Fruit final weight was subtracted from the initial weight and results expressed as percentage of loss.

Flesh firmness was assessed on both sides of each fruit (equatorial position), by using a digital penetrometer (PTR-300 model; Instrutherm - São Paulo, Brazil) with a nozzle diameter of $5 \mathrm{~mm}$. Measurements were taken after peeling a small portion of the fruit, using a blade; results were expressed in Newton (N). SS content was measured directly using a digital refractometer (PAL-1 model; Atago - Ribeirão Preto, Brazil), with automatic temperature compensation to $20{ }^{\circ} \mathrm{C}$, and results expressed as percentage. TA was determined by titration of sample with $0.01 \mathrm{~mol} \mathrm{~L}^{-1} \mathrm{NaOH}$, using $1 \%$ phenolphthalein indicator, and results were expressed as percentage of citric acid. The ratio SS/ TA was calculated using SS (\%) and TA (\%), and results expressed in absolute values. Then, $\mathrm{pH}$ readings were directly taken by a digital $\mathrm{pH}$ meter
(MPA-210 model; Tecnopon - Piracicaba, Brazil), also being expressed in absolute values.

\section{Sensory analysis}

The University Ethics Committee on Human Research approved the study protocol (approval number 32222114.8.0000.5153). On the fourth day of storage, tasters evaluated the fruit between $14 \mathrm{~h} 00$ and $16 \mathrm{~h} 00$. These appraisers consisted of students, faculty members, and staff of the university (UFV/ CRP), aging between 18 and 61 years, who were selected for being papaya consumers and based on their availability and interest in participating in such a project.

In total, 54 untrained tasters participated in the sensory analysis. These people tasted five papaya samples representative of each treatment (control, alcohol, 2.5\% propolis, 5\% propolis, and refrigerated). Each one of them was served a $20-\mathrm{g}$ sample (coded with three-digit numbers) in white plastic cup identified by a three-digit code (REIS; MINIM, 2010). The samples were accompanied by a glass of water at room temperature, for ingestion between one sample to the other, and for palate cleansing. Sample taste was evaluated according to a hedonic scale of 1 to 9 , in which 9 was "extremely liked" and 1 was "extremely disliked", according to the methodology described by Dutcosky (2013).

\section{Statistical analysis}

The data were subjected to the Hartley's test for homogeneity of variances and Jarque-Bera's test for normality of residuals. The variables firmness and $\mathrm{SS} / \mathrm{TA}$ ratio underwent $\log (\mathrm{x}+1)$ transformations prior to variance analysis (ANOVA).

Postharvest treatment and storage time influences and their interactions were submitted to a split-plot analysis. After ANOVA splitting, the averages of postharvest treatments (main study focus) were compared by the Student-Newman-Keuls's test (SNK), at $5 \%$ probability. It was selected because it is 
more powerful than the Tukey's test and for owning a tight control on actual type-1 error (PERECIN; BARBOSA, 1988). Postharvest treatment averages underwent regression analysis whilst assessed, fitting data to two-factor models.

Sensory analysis experimental design was randomized block with 54 repetitions. Classification data was transformed into numerical values for analysis, using ANOVA at 5\% significance level and variance ratio $\mathrm{F}$ to detect significant differences.

\section{Results and Discussion}

Weight loss

Both postharvest treatments and days of storage had significant effect on papaya weight loss, gradually increasing throughout storage for all treatments, but less marked in refrigerated fruit (Table 1).

Table 1 . Percent weight loss of Solo papaya cv. 'Golden' both coated and uncoated with propolis extract during storage period

\begin{tabular}{|c|c|c|c|c|c|c|}
\hline Treatments & 4 days & 8 days & 12 days & Means & Adjusted model & $\mathrm{R}^{2}$ \\
\hline Control & $3.85 A$ & $6.75 A$ & $10.98 A$ & 7.19 & $y=0.0419 x^{2}+0.2217 x+2.2943$ & 0.999 \\
\hline Alcohol & $3.56 \mathrm{~A}$ & $6.52 \mathrm{~A}$ & $10.71 A$ & 6.93 & $\mathrm{y}=0.0383 x^{2}+0.2809 x+1.8239$ & 0.999 \\
\hline $2.5 \%$ propolis & $2.25 B$ & $4.17 B$ & $7.48 B$ & 4.63 & $y=0.0431 x^{2}-0.0361 x+1.7028$ & 0.999 \\
\hline $5 \%$ propolis & $1.85 B$ & $3.70 B$ & $7.41 B$ & 4.32 & $y=0.0576 x^{2}-0.2277 x+1.8363$ & 0.999 \\
\hline Refrigerated & $1.90 B$ & $3.35 B$ & $4.83 C$ & 3.36 & $y=0.3662 x+0.4337$ & 0.999 \\
\hline Means & 2.68 & 4.90 & 8.28 & & & \\
\hline $\mathrm{CV}$ & $13.2 \%$ & & & & & \\
\hline
\end{tabular}

Means followed by different letters in the same column indicate the significant differences between the postharvest treatments (SNK test, $\mathrm{p}<0.05$ ).

It is noteworthy mention that control and alcohol treatments showed the highest weight losses. Ali et al. (2015) observed a similar trend in bell peppers; these authors noted that uncoated and alcoholcoated fruit had greater weight loss. While bell pepper coated with higher concentrations of ethanolextracted propolis improved the water vapor and gas exchange barrier properties during storage.

In papaya, it is believed that the major pathway for weight loss is through the peel (CHITARRA; CHITARRA, 2005). According to the authors, peel integrity decline from fruit ripening is due to latex disruption. Generally, a 10\% weight loss makes one fruit unfit for consumption (KADER, 2002). In this study, the treatments able to restrain weight losses for 12 days of storage were refrigerated, $2.5 \%$ propolis, and $5 \%$ propolis. Considering a $10 \%$ weight loss and the adjusted regression equations in Table 1, "control" and "alcohol" treatments were considered unfit for consumption from the $11^{\text {th }}$ day of storage onwards; yet propolis-extract coated fruit were taken as unfit after nearly 14 days of storage. As a rule, $2.5 \%$ and $5 \%$ propolis coating restrained papaya weight loss and may extend in $27 \%$ storage period, when compared to control. Yet refrigerated treatment became unfit for consumption after 26 days of storage.

Until the $8^{\text {th }}$ day of storage, weight loss of propolis extract-coated papaya was similar to that of fruit kept under refrigeration, but lesser than that of postharvest control and alcohol treatments. At 12 days of storage, propolis extract coating promoted higher fruit weight loss than refrigeration, however, being significantly lower than control and alcohol treatments. Fruit stored at $9 \pm 1{ }^{\circ} \mathrm{C}$ had less weight loss, differing significantly from other postharvest 
treatments, at 12 days of storage. Refrigeration slowed perspiration, respiration, and ripening, reducing thus fruit weight losses. Conversely, refrigerated fruit showed chilling injuries, with no climacteric peak, as characterized by pulp hardening and changes in peel and pulp staining. This can be attributed to inhibition of pectin solubilization and hydrolysis of chlorophyll, as well as synthesis of carotenoids (CHITARRA; CHITARRA, 2005). Almeida et al. (2005) reported similar results in Solo papaya stored at $6^{\circ} \mathrm{C}$.

Propolis extract coatings contributed to gases and water vapor permeability properties, being weight losses directly related to fruit respiration and perspiration rates. In other words, this superficial thin coating interfered with fruit breathing and diffusive mechanisms (ALI et al., 2015; ALI et al., 2011).

In contrast, $2.5 \%$ and $5 \%$ propolis extract coating were not efficient to prevent germination of filamentous fungi from the $8^{\text {th }}$ day of storage. The infection by these fungi can start during postharvest treating, fruit selection, or even while storing at room temperature and in cold rooms (SILVA; SOARES, 2001). Contamination routes might occur due to fungal inoculum on walls, on packaging materials, and scattered throughout the air (OLIVEIRA; SANTOS FILHO, 2007).

On the $12^{\text {th }}$ day of storage, fruit of all postharvest treatments were unsuitable for marketing, given the large concentration of fungal spores on their surfaces.
A critical point for propolis extract efficiency as papaya coating may be related to layer thickness. When extremely thin, it lacks effect on water loss and, when highly thick, leads to fruit internal breakdown and thereby increase fungal infection (CHITARRA; CHITARRA, 2005). Combining propolis extract with another coating material may improve control of plant diseases in papaya (ALI et al., 2015; ALI et al., 2014; TORLAK; SERT, 2013; ZAHID et al., 2013).

Temperature and $\mathrm{RH}$ have great influence on postharvest papaya quality. Oscillations of these variables increase water losses, releasing free water on fruit surface that is diffusely vaporized to the environment at low humidity, constituting favorable conditions for fungal germination and subsequent penetration (CHITARRA; CHITARRA, 2005; LEE et al., 1996).

\section{Firmness}

Fruit firmness had no influence of postharvest treatments, neither storage period, with no significant interaction between both of them. Fruit coated with alcohol and 2.5\% propolis did not differ from control, showing thus lower values. Unlike that, 5\% propolis provided firmer fruit in comparison with control. Moreover, refrigerated fruit differed significantly from all postharvest treatments, showing greatest firmness in all tested periods (Table 2).

Table 2. Firmness (N) of Solo papaya cv. 'Golden' both coated and uncoated with propolis extract during storage period.

\begin{tabular}{lcccccccc}
\hline Treatments & $\begin{array}{c}\text { Initial } \\
\text { value }\end{array}$ & 4 days & 8 days & 12 days & Means & Adjusted model & $\mathrm{R}^{2}$ \\
\hline Control & 10.52 & 3.44 & 2.59 & 1.66 & 2.56 & $C$ & & \\
Alcohol & & 1.69 & 2.00 & 1.18 & 1.62 & $C$ & & \\
2.5\% propolis & & 2.79 & 3.60 & 1.71 & 2.70 & $C$ & & \\
5\% propolis & & 7.62 & 3.51 & 2.74 & 4.62 & $B$ & & \\
Refrigerated & 9.02 & 6.31 & 9.72 & 8.35 & $A$ & & \\
\hline Means & & & & & & \\
\hline CV & 32.91 & 3.60 & 3.40 & & & & & \\
\hline
\end{tabular}

Means followed by different letters in the same column indicate significant differences between postharvest treatments (SNK test, $\mathrm{p}<0.05)$. 
Within the 12 days of storage, a decreased fruit firmness was noted in all postharvest treatments, except for the refrigerated one. Such outcome was more pronounced on the $8^{\text {th }}$ day. Hydrolytic enzymes such as pectin methylesterase (PME) and polygalacturonase $(\mathrm{PG})$ breakdown carbohydrates, causing fruit loss of firmness (CHITARRA; CHITARRA, 2005). PME activity may decrease, remain constant, or increase throughout maturation, depending on fruit type and enzyme extraction method (PINTO et al., 2011). These changes were hampered by PME inhibitors such as sucrose, maltose, and glucose through non-competitive inhibition, as well as by competition of some peptides for PME bonding sites (ALI et al., 2004). PG is highly active in the early ripening stages and thereby contributes to pulp softening (BONNIN et al., 2014). In this way, a significant initial activity of PME make available the substrate for PG (PINTO et al., 2011). In this line, Bonnin et al. (2014) reported that PME promotes partial demethylation of methyl esters from polygalacturonic and pectic acids, promoting depolymerization and solubilization of pectic compounds by $\mathrm{PG}$.

Fruit firmness after 12 days of storage under refrigeration suggests fruit pulp hardening, being visually checked. This may be a result from a late ripening due to chilling injuries, even if fruit had been maintained within a SMT range. Almeida et al. (2005) and Rocha et al. (2005) reported a similar trend for refrigerated papaya, wherein fruit severely chill injured had ripening fully inhibited.

\section{SS}

Postharvest treatments influenced the content of SS, with no significant effect of storage periods or of the interaction between both factors. After 12 days of storage, results obtained for 5\% propolis differed significantly from those of alcohol treatment, without significant differences with the other treatments (Table 3).

Table 3. Soluble solids concentration (\%) of Solo papaya cv. 'Golden' both coated and uncoated with propolis extract during storage period.

\begin{tabular}{lcccccl}
\hline Treatments & $\begin{array}{c}\text { Initial } \\
\text { value }\end{array}$ & 4 days & 8 days & 12 days & Means & \\
\hline Control & 12.28 & 12.68 & 12.26 & 11.35 & 12.10 & $A B$ \\
Alcohol & & 12.14 & 11.60 & 11.07 & 11.60 & $B$ \\
$2.5 \%$ propolis & & 12.13 & 12.05 & 11.72 & 11.96 & $A B$ \\
$5 \%$ propolis & & 13.25 & 12.85 & 12.10 & 12.73 & $A$ \\
Refrigerated & 12.33 & 11.60 & 12.52 & 12.15 & $A B$ \\
\hline Means & & 12.51 & 11.75 & CV: $7.8 \%$ & \\
\hline
\end{tabular}

Means followed by different letters in the same column indicate the significant differences between postharvest treatments (SNK test, $\mathrm{p}<0.05)$.

The contents of SS were above the minimum of $11 \%$ established by the Technical Regulation on Quality of Papaya (BRASIL, 2010). These results corroborate the findings of Azene et al. (2011) and Gómez et al. (2002), in which the amount of SS had no significant changes during ripening of papaya fruit, with values of nearly $12 \%$.

Such levels of SS value throughout ripening process can be justified by a low starch accumulation
$(<1 \%)$ along its development, decreasing variations of soluble sugars during ripening (GÓMEZ et al., 2002). According to Chitarra and Chitarra (2005), fruit soluble sugar levels remain high while still attached to the plant, probably owing to photosynthesis. Glucose is the dominant sugar in the early development of papaya fruit, whereas in the advanced stages, sucrose content increases up to levels above those of fructose and glucose (KADER, 2002). 
$T A$

TA was influenced by storing period, but not by postharvest treatment, without any interaction between these factors. This variable showed a significant quadratic behavior and decline in value, followed by an increase, as observed in Table 4 .

his initial fall in TA could be explained by an increasing consumption of organic acids during respiratory process, being converted into simple sugars (OLIVEIRA JUNIOR et al., 2006; CHITARRA; CHITARRA, 2005). The later increase in TA may be associated with the formation of galacturonic acid from pectin hydrolysis by PME and PG (BONNIN et al., 2014; PINTO et al., 2011). The metabolic activity increase at climacteric peak could have contributed to the synthesis of organic acids (PAULL; CHEN, 1983).

Some authors have reported TA increases papaya ripening (REIS SILVA; MEDINA, 1997), while some others claim that such acidity decreases in fully ripe fruit (ZAHID et al., 2013; AZEVEDO et al., 2008; CHITARRA; CHITARRA 2005). Ali et al. (2011) also observed a decrease in TA for Solo papaya 'Eksotika II' coated with chitosan, regardless of storage time, which ultimately led to fruit senescence.

Table 4. Titratable acidity (\%) of Solo papaya cv. 'Golden' both coated and uncoated with propolis extract during storage period.

\begin{tabular}{lcccccccc}
\hline Treatments & $\begin{array}{c}\text { Initial } \\
\text { value }\end{array}$ & 4 days & 8 days & 12 days & Means & Adjusted model & $\mathrm{R}^{2}$ \\
\hline Control & 0.05 & 0.04 & 0.04 & 0.06 & 0.05 & $A$ & \\
Alcohol & & 0.04 & 0.05 & 0.06 & 0.05 & $A$ & \\
2.5\% propolis & & 0.05 & 0.04 & 0.04 & 0.04 & $A$ & \\
5\% propolis & & 0.05 & 0.04 & 0.05 & 0.05 & $A$ & & \\
Refrigerated & & 0.05 & 0.04 & 0.06 & 0.05 & $A$ & & \\
\hline Means & 0.05 & 0.04 & 0.05 & & $\mathrm{y}=0.0003 \mathrm{x}^{2}-0.0037 \mathrm{x}+0.055$ & 0.983 \\
\hline CV & $22.4 \%$ & & & & \\
\hline
\end{tabular}

Means followed by different letters in the same column indicate the significant differences between postharvest treatments (SNK test, $\mathrm{p}<0.05)$.

\section{$S S / T A$}

The ratio SS/TA varied significantly with storage time, without any significant changes by postharvest treatment nor interactions between both factors. This ratio increased until the $8^{\text {th }}$ day, from which it was observed a subsequent decrease. Since no significant changes were observed for SS content during storage period (Table 3), SS/ TA changes can be attributed to alterations of TA levels (Table 4), which decreased until the $8^{\text {th }}$ day of storage, increasing again at the end of the study period (Table 5).
This ratio ranged between 196.52 and 309.25 , which resulted in higher values than those obtained by Fagundes and Yamanishi (2001) for Solo papaya (74.7-275.7). Organic acids and sugars were major contributors to fruit taste and flavor. This relationship, known as maturity index (AGUSTÍ, 2000 ), indicates the proportion of sugars and acids inside the fruit, however, singly, they should not be as quality index for such products (CHITARRA; CHITARRA, 2005). 
Table 5. Ratio of soluble solids and titratable acidity (SS/TA) of Solo papaya cv. 'Golden' both coated and uncoated with propolis extract during storage period.

\begin{tabular}{lccccccc}
\hline Treatments & $\begin{array}{c}\text { Initial } \\
\text { value }\end{array}$ & 4 days & 8 days & 12 days & Means & Adjusted model & $\mathrm{R}^{2}$ \\
\hline Control & 237.74 & 309.25 & 301.45 & 196.52 & 269.07 & $A$ & \\
Alcohol & & 276.18 & 260.34 & 208.58 & 248.37 & $A$ & \\
2.5\% propolis & 256.26 & 271.93 & 291.24 & 273.14 & $A$ & & \\
5\% propolis & 292.00 & 306.24 & 233.21 & 277.15 & $A$ & & \\
Refrigerated & 300.66 & 302.96 & 227.23 & 276.95 & $A$ & & \\
\hline Means & 286.87 & 288.58 & 231.36 & & $\log (\mathrm{y}+1)=-0.0025 \mathrm{x}^{2}+0.03 \mathrm{x}+2.3624$ & 0.999 \\
CV & $4.2 \%$ & & & & & & \\
\hline
\end{tabular}

Means followed by different letters in the same column indicate the significant differences between postharvest treatments (SNK test, $\mathrm{p}<0.05$ ).

$p H$

The $\mathrm{pH}$ of fruit differed significantly among postharvest treatments and storage periods; however, there was no interaction between them.
The values ranged from 5.10 to 5.85 , being close to those obtained by Azene et al. (2011) and Fagundes and Yamanishi (2001) for the same type of papaya Solo (5.00-5.80 and 5.20-5.71, respectively) (Table $6)$.

Table 6. Hydrogen potential (pH) of Solo papaya cv. 'Golden' both coated and uncoated with propolis extract during storage period.

\begin{tabular}{lcccccc}
\hline Treatments & $\begin{array}{c}\text { Initial } \\
\text { value }\end{array}$ & 4 days & 8 days & 12 days & Means & \\
\hline Control & 5.10 & 5.55 & 5.75 & 5.76 & 5.69 & $A$ \\
Alcohol & & 5.64 & 5.56 & 5.71 & 5.63 & $A$ \\
2.5\% propolis & & 5.70 & 5.51 & 5.82 & 5.67 & $A$ \\
$5 \%$ propolis & & 5.85 & 5.65 & 5.83 & 5.77 & $A$ \\
Refrigerated & & 5.34 & 5.16 & 5.18 & 5.23 & $B$ \\
\hline Means & & 5.61 & 5.52 & 5.66 & CV: $4.2 \%$ & \\
\hline
\end{tabular}

Means followed by different letters in the same column indicate the significant differences between postharvest treatments (SNK test, $\mathrm{p}<0.05$ ).

Generally, papaya fruit $\mathrm{pH}$ is above five, once it has a low organic acid content (FAGUNDES; YAMANISHI, 2001). The organic acids in papaya pulp are weak acids and therefore have low dissociation (ALMEIDA et al., 2006), which explains the values similar to those reported in the previous literature.

Only refrigerated fruit differed significantly from those of other treatments. The lower $\mathrm{pH}$ in papaya under cooling condition can be attributed to chilling injury, which weakens the tissues and disrupts normal metabolic processes (CHITARRA; CHITARRA, 2005). As a result, several symptoms such as abnormal maturation, coloration change, as well as losses of flavor and aroma were registered in fruit (KADER, 2002).

\section{Sensory analysis}

Sensory evaluation revealed no significant difference among postharvest treatments until the $4^{\text {th }}$ day of storage. Little influence was observed on fruit by the different coatings, however, being well 
accepted by tasters; overall, samples were scored as "slightly liked" and "moderately liked" within the hedonic scale (Table 7).

Sensory analyses were performed during evaluation period when fruit showed medium firmness, high SS, stable TA, and considerable $\mathrm{SS} / \mathrm{TA}$, which are fruit characteristics indicative of sensory quality, commonly known as maturity index (AGUSTÍ, 2000).

Table 7. Scores (means \pm standard deviation) assigned by tasters in sensory analysis of Solo papaya cv. 'Golden' both coated and uncoated with propolis extract during storage period.

\begin{tabular}{lc}
\hline Treatments & 4 days $^{1}$ \\
\hline Control & $7.00 \pm 1.58$ \\
Alcohol & $6.65 \pm 1.75$ \\
$2.5 \%$ propolis & $6.39 \pm 1.94$ \\
$5 \%$ propolis & $6.24 \pm 1.88$ \\
Refrigerated & $6.67 \pm 1.73$ \\
\hline
\end{tabular}

19-point hedonic scale (1 - disliked extremely to 9 - liked extremely).

\section{Conclusion}

Fruit coatings of $2.5 \%$ and $5 \%$ propolis extract are effective in reducing weight loss of Solo papayas cv. 'Golden'. These treatments maintain weight losses similar to those observed for postharvest refrigeration for 8 days. Coating with $5 \%$ of propolis extract showed a positive effect on fruit firmness, being superior to control, alcohol, and $2.5 \%$ propolis extract. When exposed to a temperature of $9{ }^{\circ} \mathrm{C}$ for 12 days, papaya fruit showed chilling injuries. On one hand, propolis coating provided contents of SS, TA and SS/TA that are similar to those of the other postharvest treatments. On the other hand, it was not effective in controlling filamentous fungi, limiting thus postharvest quality. There were no sensory changes among postharvest treatments until the $4^{\text {th }}$ day of storage. Overall, our results suggest that coating with hydroalcoholic extract of propolis can act as an adjuvant, which may reduce synthetic packaging and alterations on favorable storage conditions such as refrigeration or controlled atmospheres, thereby limiting preservation costs incurred in papaya storing.

\section{Acknowledgments}

To Coordenação de Aperfeiçoamento de Pessoal de Nivel Superior (CAPES - Brazilian Ministry of Education) for granting the research fellowships.

\section{References}

INSTITUTO ADOLFO LUTZ - IAL Métodos físicoquímicos para análise de alimentos. 4. ed. Brasília: Ministério da Saúde, 2004. 1018 p.

AGUSTÍ, M. Crecimiento y maduración del fruto. In: AZCÓN-BIETO, J.; TALÓN, M. Fundamentos de fisiologia vegetal. Barcelona: Edicions Universitat de Barcelona, 2000. cap. 6, p. 419-433.

ALI, A.; CHOW, W. L.; ZAHID, N.; ONG, M. K. Efficacy of propolis and cinnamon oil coating in controlling postharvest anthracnose and quality of chilli (Capsicum annuиm L.) during cold storage. Food and Bioprocess Technology, New York, v. 7, n. 9, p. 2742-2748, 2014.

ALI, A.; MUHAMMAD, M. T. M.; SIJAM, K.; SIDDIQUI, Y. Effect of chitosan coatings on the physicochemical characteristics of Eksotika II papaya (Carica papaya L.) fruit during cold storage. Food Chemistry, Oxford, v. 124, n. 2, p. 620-626, 2011.

ALI, A.; WEI, Y. Z.; MUSTAFA, M. A. Exploiting propolis as an antimicrobial edible coating to control post-harvest anthracnose of bell pepper. Packaging Technology and Science, Singapore, v. 28, n. 2, p. 173179, 2015. 
ALI, Z. M.; CHIN, L.; LAZAN, H. A comparative study on wall degrading enzymes, pectin modifications and softening during ripening of selected tropical fruits. Plant Science, Limerick, v. 167, n. 2, p. 317-327, 2004.

ALMEIDA, R. F.; MARTINS, M. L. L.; RESENDE, E. D.; VITORAZI, L.; CARLOS, L. A.; PINTO, L. K. A. Influence of the refrigerating temperature on the chemical characteristics of papaya fruits cv. Golden. Ciência e Tecnologia de Alimentos, Campinas, v. 26, n. 3, p. 577-581, 2006.

ALMEIDA, R. F.; RESENDE, E. D.; VITORAZI, L.; CARLOS, L. A.; PINTO, L. K. A.; SILVA, H. R. F.; MARTINS, M. L. L. Injúria pelo frio em frutos de mamoeiro (Carica papaya L.) cv 'Golden'. Revista Brasileira de Fruticultura, Jaboticabal, v. 27, n. 1, p. 1720, 2005.

AZENE, M.; WORKNEH, T. S.; WOLDETSADIK, K. Effect of packaging materials and storage environment on postharvest quality of papaya fruit. Journal of Food Science and Technology, Oxford, v. 48, n. 6, p. 1-15, 2011.

AZEVEDO, I. G.; OLIVEIRA, J. G.; SILVA, M. G.; PEREIRA, T.; CORREIA, S. F.; VARGAS, H.; FAÇANHA, A. R. P-type H+-ATPases activity, membrane integrity, and apoplastic $\mathrm{pH}$ during papaya fruit ripening. Postharvest Biology and Technology, Amsterdam, v. 48, n. 1, p. 242-247, 2008.

BONNIN, E.; GARNIER, C.; RALET, M. C. Pectinmodifying enzymes and pectin-derived materials: applications and impacts. Applied Microbiology and Biotechnology, Berlin, v. 98, n. 2, p. 519-532, 2014.

BRASIL. MINISTÉRIO DA AGRICULTURA, PECUÁRIA E ABASTECIMENTO - MAPA. Instrução Normativa $\mathrm{n}^{\circ} 4$, de 22 de janeiro de 2010. Estabelece o regulamento técnico do mamão. Diário Oficial [da] República Federativa do Brasil, Brasília, Seção 1, p. 3, 2010.

CARVALHO, J. X.; SUÁREZ, R. O.; MENDES, F. Q.; FERNANDES, R. V. B.; CUNHA, M. C.; CARVALHO, A. M. X. Extensão da vida de prateleira de ovos pela cobertura com própolis. Semina: Ciências Agrárias, Londrina, v. 34, n. 5, p. 2287-2296, 2013.

CHITARRA, M. I. F.; CHITARRA, A. B. Pós-colheita de frutas e hortaliças: fisiologia e manuseio. 2. ed. Lavras: Editora UFLA, 2005. 785p.

DAIUTO, E. R.; MINARELLI, P. H.; VIEITES, R. L.; ORSI, R. O. Própolis e cera vegetal na conservação de abacate 'Hass'. Semina: Ciências Agrárias, Londrina, v. 33, n. 4, p. 1463-1474, 2012.
DUTCOSKY, S. D. Análise sensorial de alimentos. 4. ed. rev. ampl. Curitiba: Champagnat, 2013. 531 p.

FAGUNDES, G. R.; YAMANISHI, O. K. Características físicas e químicas de frutos de mamoeiro do grupo 'Solo' comercializados em 4 estabelecimentos de Brasília-DF. Revista Brasileira de Fruticultura, Jaboticabal, v. 23, n. 3, p. 541-545, 2001.

FOOD AND AGRICULTURE ORGANIZATION OF THE UNITED NATIONS - FAO. FAOSTAT. Estatistical Databases Agriculture. 2014. Available at: <http:// faostat.fao.org/>. Accessed at: 10 sept. 2015.

GÓMEZ, M.; LAJOLO, F.; CORDENUNSI, B. Evolution of solubles sugars during ripening of papaya fruit and its relation to sweet tast. Journal of Food Science, Chicago, v. 67, n. 1, p. $442-447,2002$.

INSTITUTO BRASILEIRO DE GEOGRAFIA E ESTATÍSTICA - IBGE. Produção agrícola municipal: culturas temporárias e permanentes. Rio de Janeiro: IBGE, v. 40, 2013. 100 p.

KADER, A. A. Postharvest technology of horticultural crops. 3. ed. California: University of California, 2002. $535 \mathrm{p}$.

LEE, L.; ARUL, J.; LENCKI, R.; CASTAIGNE, F. A review on modified atmosphere packaging and preservation of fresh fruits and vegetables. Physiological basis and practical aspects. Packaging Technology and Science, London, v. 9, n. 6, p. 315-331, 1996.

MENEGUEL, R. F. A.; BENASSI, M. T.; YAMASHITA, F. Revestimento comestível de alginato de sódio para frutos de amora-preta (Rubus ulmifolius). Semina:Ciências Agrárias, Londrina, v. 29, n. 3, p. 609-618, 2008.

OLIVEIRA JUNIOR, L. F. G.; COELHO, E. M.; COELHO, F. C. Caracterização pós-colheita de mamão armazenado em atmosfera modificada. Revista Brasileira de Engenharia Agrícola e Ambiental, Campina Grande, v. 10, n. 3, p. 660-664, 2006.

OLIVEIRA, A. A. R.; SANTOS FILHO, H. P. Podridão de Rhizopus. Cruz das Almas: Embrapa Mandioca e Fruticultura Tropical. Mamão em foco, 2007. (Comunicado técnico, n. 26).

PASTOR, C.; SÁNCHEZ-GONZÁLES, L.; MARCILLA, A.; CHIRALT, A.; CHÁFER, M.; GONZÁLEZ-MARTÍNEZ, C. Quality and safety of table grapes coated with hydroxypropylmethylcellulose edible coatings containing propolis extract. Postharvest Biology and Technology, Amsterdam, v. 60, n. 1, p. 6470, 2011. 
PAULL, R. E.; CHEN, N. J. Postharvest variation in cell wall-degradin enzymes of papaya (Carica papaya L.) during fruit ripening. Plant physiology, Waterbury, v. 72, n. 2, p. 382-385, 1983.

PERECIN, D.; BARBOSA, J. C. Uma avaliação de seis procedimentos para comparações múltiplas. Revista Matemática e Estatística, São Paulo, v. 6, n. 1, p. 95-103, 1988.

PINTO, L. K. A.; MARTINS, M. L. L.; RESENDE, E. D.; THIÈBAUT, J. T. L. Atividade da pectina metilesterase e da $\beta$-galactosidase durante o amadurecimento do mamão cv. Golden. Revista Brasileira de Fruticultura, Jaboticabal, v. 33, n. 3, p. 713-722, 2011.

PIZATO, S.; CORTEZ-VEGA W.; PRENTICEHERNÁNDEZ, C.; BORGES, C. D. Effect of applying different edible coatings on conservation of minimally processed 'Royal Gala' apples. Semina: Ciências Agrárias, Londrina, v. 34, n. 1, p. 253-264, 2013.

\section{PROGRAMA BRASILEIRO PARA A} MODERNIZAÇÃO DA HORTICULTURA. Normas de classificação de mamão. São Paulo: CEAGESP, Centro de Qualidade em Horticultura, 2005. 6 p. (CQH. Documentos).

REIS SILVA, J. R.; MEDINA, V. M. Alterações bioquímicas durante o desenvolvimento do fruto do mamoeiro "Sunrise Solo". Revista Brasileira de Fruticultura, Cruz das Almas, v. 19, n. 2, p. 149-158, 1997.

REIS, R. C.; MINIM, V. P. R. Teste de aceitação. In: MINIM, V. P. R. Análise sensorial: estudos com consumidores. 2. ed. Viçosa: Ed. UFV, 2010. cap. 3, p. 66-82.
ROCHA, R. H. C.; NASCIMENTO, S. R. C.; MENEZES, J. B.; NUNES, G. H. S.; SILVA, E. O. Qualidade pós-colheita do mamão Formosa armazenado sob refrigeração. Revista Brasileira de Fruticultura, Jaboticabal, v. 27, n. 3, p. 386-389, 2005.

SERRANO, L. A. L.; CATTANEO, L. F. O cultivo do mamoeiro no Brasil. Revista Brasileira de Fruticultura. Jaboticabal, v. 32, n. 3, p. 1-1, 2010.

SILVA, D. A.; OLIVEIRA, J. K.; SANTOS, C. M.; BERY, C. C. S.; CASTRO, A. A.; SAANTOS, J. A. B. The use of sodium alginate-based coating and cellulose acetate in papaya post-harvest preservation. Acta Scientiarum. Technology, Maringá, v. 36, n. 3, p. 569-573, 2014.

SILVA, O. F.; SOARES, A. G. Recomendações para prevenção de perdas pós-colheita do mamão. Rio de Janeiro: Embrapa Agroindústria de Alimentos, 2001. 20 p.

TORLAK, E.; SERT, D. Antibacterial effectiveness of chitosan-propolis coated polypropylene films against foodborne pathogens. International Journal of Biological Macromolecules, Amsterdam, v. 60, n. 1, p. 52-55, 2013.

UZEL, A.; SORKUN, K.; ONCAG, K. O.; COGULU, D.; GENCAY, O.; SALIH, B. Chemical compositions and antimicrobial activities of four different Anatolian propolis samples. Microbiological Research, Berlin, v. 160, n. 2, p. 189-195, 2005.

ZAHID, N.; ALI, A.; SIDDIQUI, Y.; MAQBOOL, M. Efficacy of ethanolic extract of propolis in maintaining postharvest quality of dragon fruit during storage. Postharvest Biology and Technology, Amsterdam, v. 79, n. 1, p. 69-72, 2013. 